\title{
ARE CITY FISCAL WOES WIDESPREAD? ARE PENSIONS THE CAUSE?
}

\author{
By Alicia H. Munnell, Jean-Pierre Aubry, Josh Hurwitz, and Mark Cafarelli*
}

\section{INTRODUCTION}

The bankruptcy of Detroit has focused attention on the financial outlook for cities and the role that pensions may play in determining their future. Some commentators presume that excessive unfunded pension commitments will lead to widespread bankruptcies. Chicago is frequently cited as the poster child of a city where substantial pension commitments and lack of funding have led to serious financial problems. The question is whether Chicago is unique or the tip of the iceberg. To answer that question, this brief explores the extent to which economic factors, poor fiscal management, and high pension costs contribute to cities being in the news for financial problems.

The discussion proceeds as follows. The first section describes the rationale for using press reports

* Alicia H. Munnell is director of the Center for Retirement Research at Boston College (CRR) and the Peter F. Drucker Professor of Management Sciences at Boston College's Carroll School of Management. Jean-Pierre Aubry is assistant director of state and local research at the CRR. Josh Hurwitz is a former research associate at the CRR. Mark Cafarelli is a research associate at the CRR. The authors thank Kimberly Blanton for preparing the supplement of city summaries. They thank David Blitzstein, Keith Brainard, Steven Kreisberg, Ian Lanoff, and Nathan Scovronick for helpful comments. to identify troubled cities and the sample of cities included in the analysis. Since one-third of the troubled cities are located in California, the second section explores possible explanations for its high incidence of financial problems. The third section presents a regression that relates the probability of being in the news to economic, management, and pension factors. The fourth section presents a twofold conclusion. First, the image that American cities are about to topple like dominoes is not accurate. About 13 percent of the cities and towns in our local sample has been cited in the press as having financial problems, which is not surprising in the wake of the 2008 financial crisis and the Great Recession. Second, fiscal mismanagement and economic issues are more important than pensions in explaining why cities are identified as being in financial trouble.

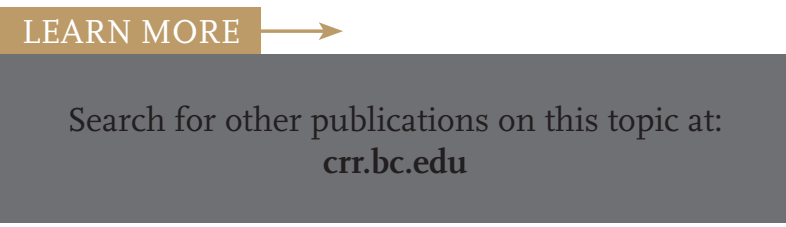




\section{The SAmple}

Instead of reviewing the finances of each of the 24,000 cities and towns in the U.S. Census of Governments, we decided to search newspapers, magazines, wire services and other sources for cities or towns that have been cited in the press as financially troubled. The search, which used the term "municipality" and either "chapter 9," "bankruptcy," or "financial problems" as additional search terms, produced articles on 41 cities and towns. Nine of those identified were very small entities that had lost a major lawsuit (and thus not included in our list); the other 32 were larger cities and small towns with issues other than litigation. The final list of flagged localities is shown in Table 1 , and some background on each locality can be found in a supplemental document.

Table 1. Localities Cited in Press as Having Financial Problems, 2007-2013

\begin{tabular}{ll}
\hline State & City \\
\hline AL & Prichard* \\
CA & $\begin{array}{l}\text { Bakersfield, Compton*, El Monte*, Fresno, } \\
\text { Los Angeles, Oakland, San Bernardino*, }\end{array}$ \\
& $\begin{array}{l}\text { San Diego, Stockton, Vallejo* } \\
\text { BT }\end{array}$ \\
Bridgeport, New Haven \\
FL & Miami \\
IL & Chicago \\
IN & Gary, Ft. Wayne \\
MD & Baltimore \\
MI & Detroit, Flint, Hamtramck* \\
NJ & Newark \\
OH & Akron, Toledo \\
PA & Altoona*, Harrisburg*, Philadelphia, Pittsburgh, \\
& Scranton* \\
RI & Central Falls*, Providence \\
WA & Tacoma
\end{tabular}

Note: Cities marked with an asterisk were not originally included in the Center's database.

Sources: Lexis-Nexis database and Google using specified search terms.

Next, the list of cited localities was compared with the Center's database of 173 cities and towns. ${ }^{1}$ Twenty-two of the cities cited in the press as troubled were already included in the local database. Another ten, identified with an asterisk in Table 1, were not originally included. Eight of these ten were added to the sample used for the regression analysis. The other two (Altoona PA and Prichard AL) were excluded due to data collection constraints, so the final sample used in the analysis consisted of 181 localities.

The map in Figure 1 shows that almost one third of the troubled localities are located in California.

Figure 1. Location of Plans Cited in the Press as Having Financial Problems

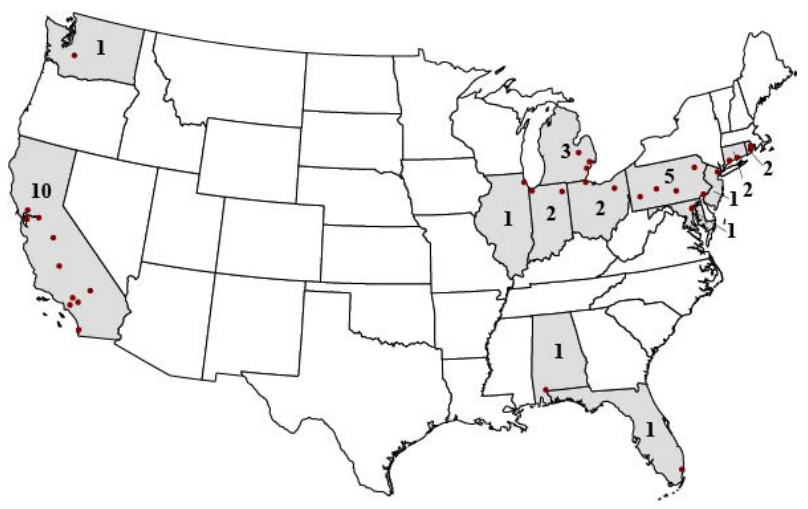

Source: Authors' illustration.

\section{What IS GOING ON IN CALIFORNiA?}

Although recently California has seen some success in stabilizing its finances through spending restraint and voter-approved tax increases, it has serious structural problems. Commentators attribute much of California's underlying problems to its brand of democracy. ${ }^{2}$ Essentially, Californians have adopted a direct and participatory democracy rather than the representative democracy favored by James Madison and other founders. The California approach opened the way for a major role for voter initiatives. These initiatives were used sparingly for much of the 20th century, but then in 1978, Californians passed Proposition 13.

Proposition 13 was a reaction to a doubling of property tax bills, as assessments soared in the early 1970s. The initiative cut the property-tax rate from an average of 2.6 percent to 1 percent in every county. It also capped the annual increase in assessed values at 2 percent, unless the property is sold. To make sure that the tax cut was not offset by tax increases elsewhere, Proposition 13 required a two-thirds super majority in the legislature for any tax hike. 
In the wake of Proposition 13, two things have happened. First, many new initiatives introduced a tax cut or an expanded service without compensating financing, so much of the budget was allocated before the legislature even had a chance to negotiate. Second, the requirement for a super majority for any revenue increase made it more difficult for policymakers to raise taxes. ${ }^{3}$ The state, in effect, lost control of its finances. ${ }^{4}$

On the pension front, California is in trouble because a retroactive expansion of benefits in the late 1990s has made the state's pensions among the highest cost in the nation. Although, unlike Illinois and New Jersey, it is not guilty of deliberating underfunding its plans, some degree of underfunding and the sheer magnitude of the pension commitments are putting enormous pressure on both state and local budgets in California. In addition, pension benefits for current employees are protected by statute, which makes it very difficult to reduce future benefits for current employees.

Finally, California was particularly hard hit by the financial crisis and ensuing recession. Even today, California has higher foreclosure and unemployment rates than most other states. And local government revenue in California grew between 2007 and 2010 by only 3 percent compared to 9 percent for the rest of the nation. ${ }^{5}$

Thus, despite the recent fiscal improvements, California continues to suffer from fiscal mismanagement, substantial pension commitments, and serious economic problems as a result of the financial crisis and ensuing recession. The question is the extent to which these three factors can explain the probability nationwide of a locality being identified in the press as facing serious financial problems.

\section{EMPIRICAL ANALYSIS}

The empirical analysis uses a probit regression to relate the probability of being flagged in the press over the period 2008-2013 to a small set of management, economic, and pension variables that are generally as of 2007.

\section{EXPLANATORY VARIABLES}

Eight variables were included in the analysis covering management, economic, and pension factors.
Financial mismanagement was captured by three variables:

- Carry deficit (2007). Cities in states where it was possible to carry deficits from one year to another and thereby circumvent the state's balanced budget mandate are likely less well managed, and thereby more likely to end up in financial distress. ${ }^{6}$

- Cash as a percent of revenue (2007). Municipalities with a low level of cash relative to revenue would be more subject to fiscal pressures and more likely to be thrown into distress by the financial crisis and ensuing recession.

- Issued Pension Obligation Bond (POB). Previous research has shown that governments that issue POBs are usually in a poor position to shoulder the investment risk. ${ }^{7}$ This variable, which takes on a value of one if the locality had issued a POB before the financial crisis, is included as a measure of poor fiscal management. ${ }^{8}$

Economic factors were also represented by three variables:

- The unemployment rate (average 2000-07). The higher the unemployment rate, the lower the revenue base, the greater demand for services, and the more vulnerable the locality to the 2008 financial collapse and ensuing recession.

- Number of foreclosures per 100,000 residences. ${ }^{9}$ This variable was measured at the state level in June 2013 to gauge the impact of the bursting of the housing bubble in different areas. ${ }^{10}$ High foreclosure rates would undermine property tax revenues, lead to a greater demand for services, and increase municipal distress.

- Peak population decline. Some cities have experienced a severe drop in their population, thereby eroding their tax base. These cities have been flagged if they saw their population peak prior to 2000.

Pension burden was measured by two variables:

- Pension costs as a percent of revenues (2007). These costs consist of both the cost of the locality's own plan and the required contribution to any stateadministered plan as a percent of own-source revenues. Higher pension costs would be expected to put additional pressure on the locality, increasing the likelihood of fiscal distress. 
- Pension protections (2007). Some states - either through constitutional provisions or case law protect future, as well as past, accruals for current employees. These protections make it very difficult to cut future benefits for current workers. Such inflexibility would be expected to increase the probability of the locality being in financial trouble. ${ }^{11}$

\section{Results}

The results of the regression are shown in Figure 2. (See the Appendix for full regression results.) The bars in the figure for "yes" " "no" variables represent the relationship between having the characteristic and the probability of being cited in the press for financial distress. For continuous variables, the bars measure the impact of a one-standard-deviation increase in the particular variable on the probability of being in the press. ${ }^{12}$ For example, localities in states that allow the carryover of deficits from one year to the next have a 10.4-percentage-point higher probability of being cited in the press for having financial problems than those localities that do not provide such flexibility. In the case of the unemployment rate, the bar indicates that a one-standard deviation increase in this measure would be associated with an additional 1.7-percentage-point likelihood of being identified as having financial difficulties.
All of the variables have the expected relationship with financial stress, and together explain about 45 percent of the variation. The ability to carry deficits, having low cash, or issuing a POB all increase the likelihood of subsequent financial problems. A higher unemployment rate, more foreclosures, and a population decline all increase the probability of financial distress. More costly pensions and constraints on adjusting future benefits for current employees also raise the likelihood of problems.

One question is the extent to which the results are being driven by California, the state with one third of the cited localities. That is, does the equation simply reflect the fact that California has management, economic, and pension problems and many financially troubled cities? Or does California have a political system that produces bad outcomes across each dimension? Two tests were performed to see whether California has a unique impact. First, a variable was added to the equation that was equal to one if the city was located in California and zero otherwise. The coefficient of that variable was not statistically significant, and its inclusion had little effect on any of the other coefficients. Even more persuasive, the equation was re-estimated excluding all California localities, and the variables had a similar impact as when California is included. (The exceptions were the coefficients on the unemployment rate and pension protections, which declined slightly and were no longer statistically significant.) Overall, these tests suggest that California is not driving the results. ${ }^{13}$

Figure 2. Marginal Impact of Selected Characteristics on the Probability of a Locality Being Cited in the Press as Financially Troubled

Carry deficit (2007)

Cash/revenue (2007)

Issued Pension Obligation Bond

Unemployment rate (2000-07)

Foreclosures per 100,000 residences

Peak population decline

Pension costs/revenues (2007)

Pension protections (2007)

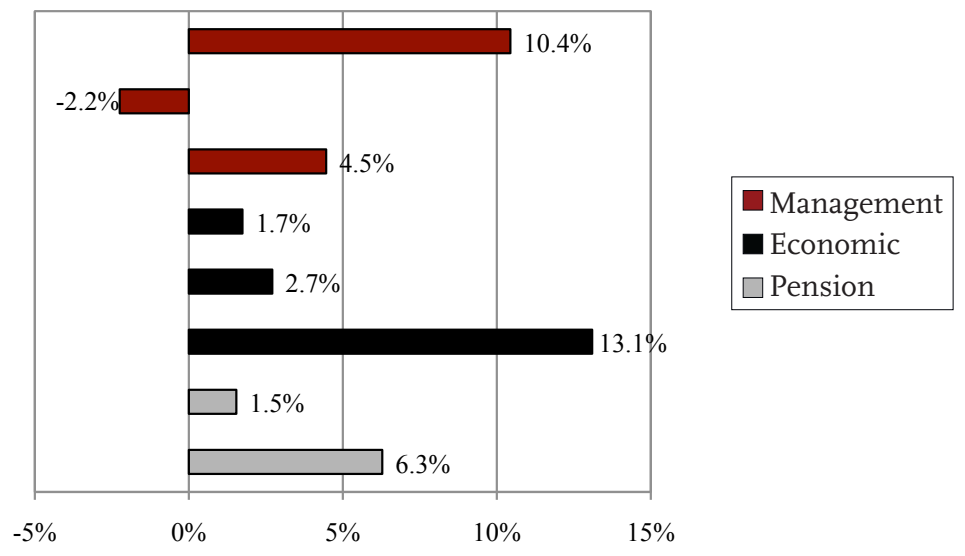

Note: All results are statistically significant at the 10-percent level or better. The bars represent a change from zero to one for dichotomous variables, and a one-standard-deviation increase for continuous variables.

Sources: Authors' calculations based on U.S. Bureau of Labor Statistics (2000-2007); National Association of State Budget Officers (2008); Public Plans Database (2007-2010); Thomson Reuters (2005-2010); and U.S. Census Bureau (1930-2010, 20002007). 
While Figure 2 shows the impact of changing individual variables, an interesting question is the relative impact of pensions as compared to economic or management factors. Such a comparison requires calculating the impact of changing all variables in one group by one standard deviation for the continuous variables and from zero to one for the dichotomous variables while holding the variables in the other two groups at their mean. Figure 3 shows the results. Management factors appear to dominate the likelihood that a locality will end up in financial trouble. The second most important factor is economic conditions. Pensions are third.

Figure 3. Marginal ImpaCt of Management, Economic, and Pension Factors on the Probability of a Locality Being Cited in the Press as Financially Troubled

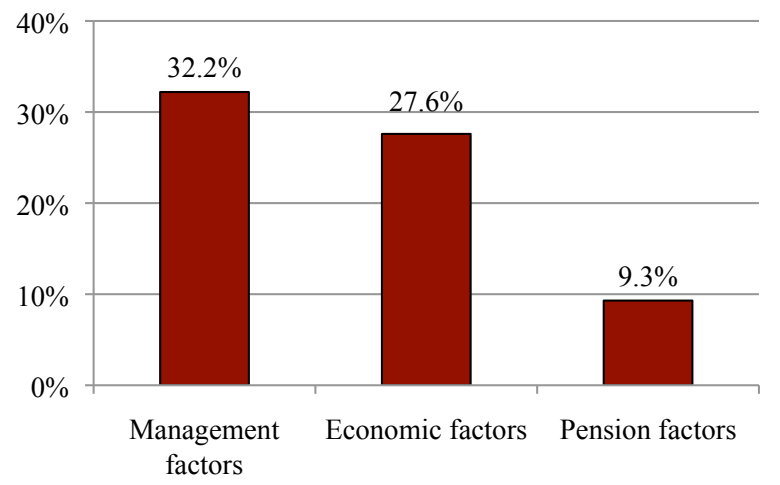

Sources: Authors' calculations based on U.S. Bureau of Labor Statistics (2000-2007); National Association of State Budget Officers (2008); Public Plans Database (2007-2010); Thomson Reuters (2005-2010); and U.S. Census Bureau (19302010, 2000-2007).

\section{CONCLUSION}

Detroit's bankruptcy has put American cities in the news. Chicago's seemingly intractable financial problems and large unfunded pension liabilities have upped the ante. The question is whether cities across the country are about to topple like dominoes. And whether pensions are the problem. The answer appears to be "no" on both fronts.

Of our original sample, 13 percent were cited in the press between 2008 and 2013 as having financial problems. This period saw the financial crisis and the worst recession since the Great Depression. Many of the troubled cities are located in California, where the state had largely lost control of its finances, where public pensions are among the highest cost in the nation, and where the bursting of the housing bubble wreaked havoc. Outside of California, the incidence of troubled cities appears to be scattered and varying in severity.

Moreover, when identifying the source of the problems, fiscal mismanagement leads the list. Economic problems, in large part a response to the financial crisis and ensuing recession, come in second. Pensions do play a role, but that role is much smaller than the other considerations.

In short, troubled cities do exist, but are not as widespread as some commentators suggest. And pensions do play a role, but they are not the major factor. 


\section{ENDNOTES}

1 While the database covers only 3.5 percent of the 24,000 localities identified in the Census, it represents about 40 percent of reported local revenues.

2 The Economist (2011a and 2011b).

3 Some suggest, though, that while Proposition 13 has been successful in constraining growth in property taxes, it has not succeeded in constraining growth in income and sales taxes. See Glyn and Drenkard (2013).

4 Some have suggested that Proposition 13's constraints on local finances may have induced cities to offer higher pensions in lieu of higher wages because pension costs can be deferred. However, we don't know of any specific evidence that supports this claim.

5 One reason for the low growth is an actual decline in state transfers, which increased elsewhere by 10 percent over the 2007-10 period. Another reason is that property taxes can drop quickly when home values fall, but the Proposition 13 cap constrains their rate of growth when values recover.

6 These states are California, Indiana, Louisiana, Michigan, Vermont, Washington, and Wisconsin.

7 See Munnell et al. (2010).

8 Since 2008, two additional cities - Lexington, KY and Bloomington, $\mathrm{MN}$ - have issued POBs.

9 RealtyTrac (2013).

10 In theory, it would be better to have foreclosure rates at the city level but such data are not readily available. Also, key states like California exhibit little in-state variation in the effects of foreclosures, reducing the advantage of having city-level data.

11 Based on Munnell and Quinby (2012), the following states were classified as having such restrictions: Alabama, California, Georgia, Kansas, Massachusetts, Nebraska, Nevada, New Hampshire, North Dakota, Oregon, Pennsylvania, Tennessee, Vermont, Washington, and West Virginia.
12 This procedure assumes that the other factors are held constant at their means. The means used in the calculations are for the original 173 localities only; the other 8 are excluded because they were specifically added to the sample only because they were identified as fiscally distressed.

13 To see if our analysis had excluded anything important, we also tried to measure the national impact of other factors illuminated by the financial distress of California cities. For example, given the potential influence of Proposition 13, we hypothesized that state property tax limitations might impact city fiscal distress across the nation. To test this notion, we added a dummy variable for property tax limitations by state; however, the results did not support the hypothesis. We then tried several other variables, such as the level of state oversight in local government finances, state transfers as a percent of own-source revenues, and political party make-up by state. However, none of these factors was associated with cities being identified as financially troubled. 


\section{REFERENCES}

Glyn, Noah and Scott Drenkard. 2013. "Prop 13 in California, 35 Years Later.” Tax Policy Blog (June 6). Washington, DC: Tax Foundation.

Munnell, Alicia H., Ashby Monk, Jean-Pierre Aubry and Thad Calabrese. 2010. "Pension Obligation Bonds: Financial Crisis Exposes Risks." State and Local Issue in Brief 9. Chestnut Hill, MA: Center for Retirement Research at Boston College. Jointly published by the Center for State and Local Government Excellence.

Munnell, Alicia H., and Laura Quinby. 2012. "Legal Constraints on Changes in State and Local Pensions." State and Local Issue in Brief 25. Chestnut Hill, MA: Center for Retirement Research at Boston College. Jointly published by the Center for State and Local Government Excellence.

National Association of State Budget Officers. 2008. "Budget Processes in the States." Washington, DC.

Public Plans Database. 2007-2010. Center for Retirement Research and Center for State and Local Government Excellence

RealtyTrac. June 2013. “U.S. Foreclosures.” Available at: http://www.realtytrac.com/statsandtrends/foreclosuretrends.

The Economist. 2011a. "Lessons from California: The Perils of Extreme Democracy.” (April 20). London, United Kingdom.

The Economist. 2011b. "Proposition 13: War by Initiative.” (April 20). London, United Kingdom.

Thomson Reuters. 2005-2010. SDC Platinum Municipal Bonds Dataset.

U.S. Bureau of Labor Statistics. 2000-2007. "Local Area Unemployment Statistics.” Washington, DC: U.S. Department of Labor.

U.S. Census Bureau. 1930-2010. Decennial Census. Washington, DC.
U.S. Census Bureau. 2000-2007. State and Local Government Finances. Washington, DC. Available at: http://www.census.gov/govs/estimate. 
APPENDIX 


\section{Appendix. Statistical Analysis}

\begin{tabular}{|c|c|c|c|c|c|}
\hline Variables & $\begin{array}{l}\text { Number of } \\
\text { observations }\end{array}$ & Mean & $\begin{array}{l}\text { Standard } \\
\text { deviation }\end{array}$ & Minimum & Maximum \\
\hline Carry deficit (2007) & 181 & 0.23 & 0.42 & 0 & 1 \\
\hline Cash/revenue (2007) & 181 & 106.75 & 64.09 & 16.08 & 442.23 \\
\hline Issued Pension Obligation Bond & 181 & 0.35 & 0.48 & 0 & 1 \\
\hline Unemployment rate (2000-07) & 181 & 4.95 & 1.19 & 2.53 & 10.06 \\
\hline $\begin{array}{l}\text { Foreclosures per } 100,000 \text { resi- } \\
\text { dences }\end{array}$ & 181 & 87.66 & 61.74 & 1.27 & 281.69 \\
\hline Peak population decline & 181 & 0.34 & 0.47 & 0 & 1 \\
\hline Pension costs/revenues (2007) & 181 & 5.84 & 3.68 & 0 & 22.30 \\
\hline Pension protections (2007) & 181 & 0.35 & 0.48 & 0 & 1 \\
\hline
\end{tabular}

Sources: Authors' calculations based on U.S. Bureau of Labor Statistics (2000-2007); National Association of State Budget Officers (2008); Public Plans Database (2007-2010); Thomson Reuters (2005-2010); and U.S. Census Bureau (1930-2010, 20002007).

Table A2. Marginal Impact of Factors Affecting the Probability of Being in the News for Financial Related Problems

\begin{tabular}{|c|c|c|c|}
\hline Variables & Full sample & $\begin{array}{c}\text { Full sample with } \\
\text { California state variable }\end{array}$ & $\begin{array}{c}\text { Excluding } \\
\text { California cities }\end{array}$ \\
\hline \multirow[t]{2}{*}{ Carry deficit (2007) } & $.104 * * *$ & $.080 * *$ & $.066 *$ \\
\hline & $(0.078)$ & $(0.080)$ & $(0.084)$ \\
\hline \multirow[t]{2}{*}{ Cash/revenue (2007) } & $0.000 * * *$ & $0.000 * * *$ & $0.000 * *$ \\
\hline & $(0.000)$ & $(0.000)$ & $(0.000)$ \\
\hline \multirow[t]{2}{*}{ Issued Pension Obligation Bond } & $0.045 * * *$ & $0.037 * *$ & $0.028 *$ \\
\hline & $(0.022)$ & $(0.026)$ & $(0.023)$ \\
\hline \multirow[t]{2}{*}{ Unemployment rate (average 2000-07) } & $0.015 * * * *$ & $0.014 * * * *$ & 0.010 \\
\hline & $(0.006)$ & $(0.007)$ & $(0.006)$ \\
\hline \multirow[t]{2}{*}{ Foreclosures per 100,000 residences } & $0.000 * * *$ & $0.000 * * *$ & $0.000 * * *$ \\
\hline & $(0.000)$ & $(0.000)$ & $(0.000)$ \\
\hline \multirow[t]{2}{*}{ Peak population decline } & $.131 * * * *$ & $.143 * * *$ & $.100 * * * *$ \\
\hline & $(0.069)$ & $(0.069)$ & $(0.052)$ \\
\hline \multirow[t]{2}{*}{ Pension costs/revenues (2007) } & $0.004 * *$ & $0.004 * *$ & $0.003 * *$ \\
\hline & $(0.003)$ & $(0.003)$ & $(0.003)$ \\
\hline \multirow[t]{2}{*}{ Pension protections (2007) } & $.063 *$ & .052 & .040 \\
\hline & $(0.042)$ & $(0.046)$ & $(0.039)$ \\
\hline \multirow[t]{2}{*}{ California } & & 0.050 & \\
\hline & & $(0.566)$ & \\
\hline Pseudo $\mathrm{R}^{2}$ & 0.448 & 0.451 & 0.444 \\
\hline Number of observations & 181 & 181 & 161 \\
\hline
\end{tabular}

Note: Robust standard errors for state-level clustering are in parentheses. * indicates statistical significance at the 10-percent level; ** indicates statistical significance at the 5-percent level; *** indicates statistical significance at the 1-percent level. Sources: Authors' calculations based on U.S. Bureau of Labor Statistics (2000-2007); National Association of State Budget Officers (2008); Public Plans Database (2007-2010); Thomson Reuters (2005-2010); and U.S. Census Bureau (1930-2010, 20002007). 


\section{About the Center}

The mission of the Center for Retirement Research at Boston College is to produce first-class research and educational tools and forge a strong link between the academic community and decision-makers in the public and private sectors around an issue of critical importance to the nation's future. To achieve this mission, the Center sponsors a wide variety of research projects, transmits new findings to a broad audience, trains new scholars, and broadens access to valuable data sources. Since its inception, the Center has established a reputation as an authoritative source of information on all major aspects of the retirement income debate.

\section{Affiliated Institutions}

The Brookings Institution

Massachusetts Institute of Technology

Syracuse University

Urban Institute

\section{CONTACT INFORMATION}

Center for Retirement Research

Boston College

Hovey House

140 Commonwealth Avenue

Chestnut Hill, MA 02467-3808

Phone: (617) 552-1762

Fax: (617) 552-0191

E-mail: crr@bc.edu

Website: http://crr.bc.edu

\section{Visit our:

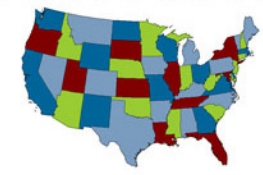 \\ PUBLIC PLANS DATABASE \\ pubplans.bc.edu}

(C) 2013, by Trustees of Boston College, Center for Retirement Research. All rights reserved. Short sections of text, not to exceed two paragraphs, may be quoted without explicit permission provided that the authors are identified and full credit, including copyright notice, is given to Trustees of Boston College, Center for Retirement Research.
The CRR gratefully acknowledges the Center for State and Local Government Excellence for its support of this research. The Center for State and Local Government Excellence (http://www.slge.org) is a proud partner in seeking retirement security for public sector employees, part of its mission to attract and retain talented individuals to public service. The opinions and conclusions expressed in this brief are solely those of the authors and do not represent the opinions or policy of the CRR or the Center for State and Local Government Excellence. 